\title{
Using the Zebrafish Lateral Line to Understand the Roles of Mitochondria in Sensorineural Hearing Loss
}

\author{
Melanie Holmgren ${ }^{1 *}$ and Lavinia Sheets ${ }^{1,2 *}$ \\ ${ }^{1}$ Department of Otolaryngology, Washington University School of Medicine, St. Louis, MO, United States, ${ }^{2}$ Department of \\ Developmental Biology, Washington University School of Medicine, St. Louis, MO, United States
}

\section{OPEN ACCESS}

Edited by:

Vincenzo Torraca,

University of London, United Kingdom

Reviewed by:

Allison B. Coffin,

Washington State University,

United States

Yingzi He,

ENT Institute and Otorhinolaryngology Department of Affiliated Eye and ENT

Hospital, China Katie Kindt,

National Institutes of Health (NIH),

United States

*Correspondence:

Melanie Holmgren

mholmgren@wustl.edu

Lavinia Sheets

sheets/@wustl.edu

Specialty section:

This article was submitted to

Molecular Medicine,

a section of the journal

Frontiers in Cell and Developmental

Biology

Received: 12 November 2020 Accepted: 23 December 2020

Published: 05 February 2021

Citation:

Holmgren $M$ and Sheets L (2021)

Using the Zebrafish Lateral Line to

Understand the Roles of Mitochondria

in Sensorineural Hearing Loss.

Front. Cell Dev. Biol. 8:628712.

doi: 10.3389/fcell.2020.628712
Hair cells are the mechanosensory receptors of the inner ear and can be damaged by noise, aging, and ototoxic drugs. This damage often results in permanent sensorineural hearing loss. Hair cells have high energy demands and rely on mitochondria to produce ATP as well as contribute to intracellular calcium homeostasis. In addition to generating ATP, mitochondria produce reactive oxygen species, which can lead to oxidative stress, and regulate cell death pathways. Zebrafish lateral-line hair cells are structurally and functionally analogous to cochlear hair cells but are optically and pharmacologically accessible within an intact specimen, making the zebrafish a good model in which to study hair-cell mitochondrial activity. Moreover, the ease of genetic manipulation of zebrafish embryos allows for the study of mutations implicated in human deafness, as well as the generation of transgenic models to visualize mitochondrial calcium transients and mitochondrial activity in live organisms. Studies of the zebrafish lateral line have shown that variations in mitochondrial activity can predict hair-cell susceptibility to damage by aminoglycosides or noise exposure. In addition, antioxidants have been shown to protect against noise trauma and ototoxic drug-induced hair-cell death. In this review, we discuss the tools and findings of recent investigations into zebrafish hair-cell mitochondria and their involvement in cellular processes, both under homeostatic conditions and in response to noise or ototoxic drugs. The zebrafish lateral line is a valuable model in which to study the roles of mitochondria in hair-cell pathologies and to develop therapeutic strategies to prevent sensorineural hearing loss in humans.

Keywords: mitochondria, hearing loss, zebrafish, hair cell, lateral line

\section{INTRODUCTION}

Hair cells are the mechanosensory receptors for hearing and balance in the inner ear. They convert vibrational stimuli into electrical signals sent to the brain. At their apical surfaces, hair cells have rows of actin-rich stereocilia (McGrath et al., 2017). Mechanical stimuli such as sound deflect these stereocilia, leading to opening of mechanotransduction (MET) channels and graded depolarization of the hair cell, a process that is modulated by $\mathrm{Ca}^{2+}$ (Mammano et al., 2007). This depolarization opens the voltage-dependent $\mathrm{L}$-type $\mathrm{Ca}^{2+}$ channels $\mathrm{Ca}_{V} 1.3$ localized at the basolateral membrane of hair cells, which drives synaptic vesicle fusion and release of glutamate onto auditory nerve fibers (Fettiplace, 2017). 
MET and synaptic transmission are energy-demanding processes, and hair cells rely on mitochondria to generate ATP through oxidative phosphorylation to meet these high metabolic demands (Puschner and Schacht, 1997). One consequence of mitochondrial oxidative phosphorylation is the production of ROS. While low levels of ROS are important for maintaining homeostatic processes by acting as signaling molecules in intracellular pathways, high ROS levels can damage cells by oxidation of macromolecules (Collins et al., 2012). Damage by mitochondrial ROS has previously been linked to aging, although the role of ROS in aging processes is not completely understood (Liochev, 2013). Mitochondria also contribute to the homeostatic control of intracellular calcium. In hair cells, mitochondria directly regulate subcellular $\mathrm{Ca}^{2+}$ concentrations by uptake through the mitochondrial $\mathrm{Ca}^{2+}$ uniporter (Matlib et al., 1998; Wong et al., 2019). Mitochondria also indirectly regulate intracellular $\mathrm{Ca}^{2+}$ clearance by providing energy to fuel ATP-dependent $\mathrm{Ca}^{2+}$ pumps (PMCA) at the plasma membrane (Zenisek and Matthews, 2000). $\mathrm{Ca}^{2+}$ signaling is complex and is involved in a wide array of cellular processes and thus must be tightly regulated (Berridge et al., 2003). Mitochondria work in conjunction with the endoplasmic reticulum (ER) to buffer intracellular $\mathrm{Ca}^{2+}$ by sequestering it into these subcellular domains (Rizzuto and Pozzan, 2006; Rizzuto et al., 2009). Cytosolic $\mathrm{Ca}^{2+}$ is also buffered by proteins such as parvalbumin and calbindin-D28k (Hackney et al., 2005). As $\mathrm{Ca}^{2+}$ regulates both MET currents and synaptic vesicle release at opposite sides of the hair cell, this local $\mathrm{Ca}^{2+}$ regulation is critical for proper hair-cell function.

Mitochondria are important mediators in various cell death pathways, including apoptosis, necrosis, and autophagy. There are two distinct apoptosis signaling pathways; both pathways rely on a group of cysteine proteases called caspases, which cleave hundreds of proteins in apoptosis. In the cell-extrinsic apoptosis signaling pathway, cell death is triggered by ligands binding to cell-surface death receptors, resulting in formation of the death-inducing signaling complex (DISC) and activation of caspase- 8 and caspase-10 (Ashkenazi, 2002). By contrast, in cell-intrinsic apoptosis signaling pathways, activation of proapoptotic Bcl-2 family proteins drives mitochondrial outer membrane permeabilization and triggers mitochondrial release of pro-apoptotic factors such as cytochrome $c$, which results in formation of the apoptosome and subsequent activation of caspase-9 (Liu et al., 1996; Du et al., 2000; Bock and Tait, 2020). These two pathways converge upon activation of the executioner caspases, caspase-3 and-7 (Bock and Tait, 2020). Necrosis and necroptosis, or programmed necrosis, are cell death pathways distinct from apoptosis and are characterized by mitochondrial swelling and impaired mitochondrial function. However, unlike apoptosis, cells that have been largely depleted of mitochondria are not resistant to necroptosis, suggesting that mitochondria are not critical for this cell death pathway (Tait et al., 2013). Autophagy, a lysosomal degradation process that can lead to cell death, has also been shown to be regulated by mitochondrial ROS (Chen et al., 2009).

Because the mitochondria play such critical roles in many cellular processes, they are increasingly being studied in the context of neural diseases, including sensorineural hearing loss (Johri and Beal, 2012; Bottger and Schacht, 2013). Hearing loss affects $23 \%$ of Americans over age 12 and has been associated with a variety of environmental causes (Goman and Lin, 2016). Acquired sensorineural hearing loss is caused by damage to hair cells and/or innervating afferent nerves. Hair cells can be damaged by excessive noise or by ototoxic drugs including aminoglycoside antibiotics and platinum-based chemotherapy drugs such as cisplatin (Lanvers-Kaminsky et al., 2017). Gradual loss of hearing, due to loss of hair cells, is also a common problem linked to aging (Schuknecht and Gacek, 1993). Because hearing loss is so prevalent and hair cell loss is permanent, there is a need to understand mechanisms of damage and to develop preventative and restorative therapies.

Zebrafish have emerged as a powerful model to investigate hearing and balance disorders. Zebrafish became established as a model organism for studying hair-cell development and function due to identification of numerous conserved genes involved in hearing and balance (Nicolson, 2017). In addition to their inner ears, which are required for hearing and balance, zebrafish also have hair cells in their lateral line organs. Unlike the sensory organs of the inner ear, lateral-line organs are located along the surface of the body, are used to detect local water currents (Dijkgraaf, 1963), and mediate behaviors such as the escape response (to avoid predation) and rheotaxis (counterflow swimming) (Olszewski et al., 2012; Suli et al., 2012; Stewart et al., 2013; Olive et al., 2016). The lateral line is made up of clusters of hair cells and supporting cells called neuromasts, which are innervated by afferent and efferent neurons (Figure 1) (Metcalfe et al., 1985; Raible and Kruse, 2000). The lateral line system in particular has become increasingly popular for studying haircell biology due to the optical and pharmacological accessibility of the neuromasts. In addition, in contrast to hair cells in the mammalian inner ear, fish hair cells in the ear and lateral line organs can regenerate after damage (Balak et al., 1990; Lombarte et al., 1993). Moreover, the generation of numerous transgenic fish lines expressing genetically encoded fluorescent reporters in hair cells offers the ability to visualize cellular and subcellular dynamics in vivo (Esterberg et al., 2014; Kindt and Sheets, 2018; Pickett et al., 2018). The zebrafish lateral line is thus a useful model system in which to study hair-cell biology and has been used to elucidate the roles of mitochondria in hair-cell pathologies and in homeostasis.

\section{IDENTIFYING ROLES OF MITOCHONDRIA IN THE LATERAL LINE UNDER HOMEOSTATIC CONDITIONS}

In addition to generating ATP and contributing to the spatial regulation of calcium within the cell, recent work has established novel roles for mitochondria in the development and maintenance of hair-cell synapses. Hair cells contain specialized electron-dense presynaptic structures, known as synaptic ribbons, that tether synaptic vesicles at the active zone and correspond with presynaptic clusters of voltage-gated Ltype calcium channels (Cav1.3) (Frank et al., 2010; Sheets et al., 
A

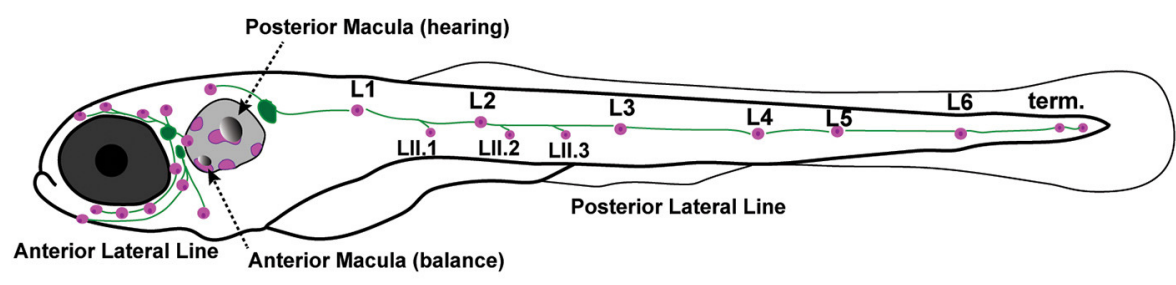

B

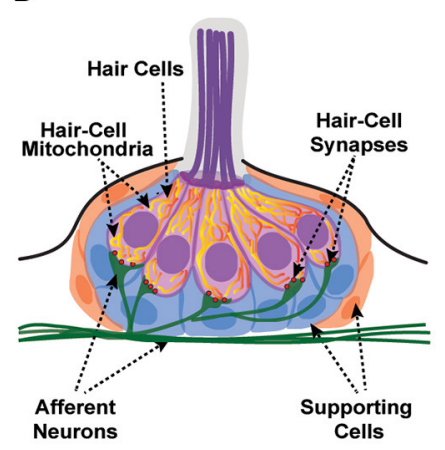

FIGURE 1 | Zebrafish lateral-line neuromasts. (A) Schematic depicts a larval zebrafish. Pink patches indicate the location of hair cells in the inner ear required for hearing and balance, as well as hair cells in the lateral-line system. Green patches represent the location of the anterior and posterior lateral-line ganglia. The cell bodies of neurons in these ganglia project to and innervate hair cells in the lateral line. (B) A side view of the anatomy of a single lateral-line neuromast. Hair cells (pink) are surrounded by supporting cells (internal, blue and peripheral, orange) and innervated by both afferent (green) and efferent neurons. Mechanosensory hair bundles (purple) at the apex of hair cells project out into the water to detect local water flow. Mitochondria (yellow, orange) make up dynamic tubular networks within hair cells. Adapted from Kindt and Sheets (2018).

2011). Vesicle fusion occurs at hair-cell ribbon synapses upon influx of $\mathrm{Ca}^{2+}$ through Cav1.3 (Brandt et al., 2003). It has been demonstrated in mammals that spontaneous $\mathrm{Ca}^{2+}$ influx through Cav1.3 occurs in developing hair cells (Marcotti et al., 2003; Tritsch et al., 2007, 2010; Eckrich et al., 2018). Previous work in zebrafish revealed a role for presynaptic $\mathrm{Ca}^{2+}$ influx in modulating synaptic ribbon size within developing lateral-line hair cells; enlarged ribbons were observed in cav1.3a mutant hair cells, or in hair cells exposed to the L-type $\mathrm{Ca}^{2+}$ channel blocker isradipine (Sheets et al., 2012), while treatment with the L-type $\mathrm{Ca}^{2+}$ channel agonist Bay K8644 led to decreased ribbon size. A recent study further defined the role of mitochondria in this process (Wong et al., 2019). Spontaneous presynaptic $\mathrm{Ca}^{2+}$ influx was observed in developing zebrafish lateral-line hair cells and, in response to this influx, mitochondria localized near synaptic ribbons showed $\mathrm{Ca}^{2+}$ uptake, a process dependent on both $\mathrm{Ca}_{\mathrm{V}} 1.3$ and the mitochondrial $\mathrm{Ca}^{2+}$ uniporter (MCU) (Wong et al., 2019). Blocking mitochondrial $\mathrm{Ca}^{2+}$ uptake with the MCU inhibitor Ru360 led to increased synaptic ribbon size in developing hair cells, demonstrating a role of mitochondrial $\mathrm{Ca}^{2+}$ signaling in ribbon formation during development.

Mitochondrial $\mathrm{Ca}^{2+}$ uptake likely regulates synaptic ribbon size by influencing $\mathrm{NAD}^{+} / \mathrm{NADH}$ redox (Jensen-Smith et al., 2012). The major structural component of synaptic ribbons is a protein called RIBEYE (Schmitz et al., 2000; Sheets et al., 2011; Lv et al., 2016). RIBEYE contains a unique A-domain and a Bdomain which is nearly identical to the transcriptional repressor protein $\mathrm{CtBP} 2$, and each domain contains binding sites that regulate the formation of RIBEYE aggregates. Notably, RIBEYE B-domain contains an $\mathrm{NAD}(\mathrm{H})$ binding site, and it has been shown in vivo that $\mathrm{NAD}(\mathrm{H})$ inhibits heteromeric interactions between RIBEYE A- and B-domains (Magupalli et al., 2008). In zebrafish hair cells, blocking mitochondrial $\mathrm{Ca}^{2+}$ uptake with Ru360 or inhibiting Cav1.3 with isradipine resulted in increased $\mathrm{NAD}^{+} / \mathrm{NADH}$ ratio (Wong et al., 2019). Exogenously manipulating $\mathrm{NAD}^{+} / \mathrm{NADH}$ also altered presynaptic ribbon sizes in developing hair cells, such that treatment with $\mathrm{NAD}^{+}$ led to enlarged ribbons, while treatment with NADH decreased ribbon size. Cumulatively, these data support that spontaneous hair-cell activity and mitochondrial $\mathrm{Ca}^{2+}$ accumulation regulates $\mathrm{NAD}^{+} / \mathrm{NADH}$ redox, which in turn modulates synaptic ribbon assembly in developing hair cells.

In addition to playing a key role in development of haircell synapses, mitochondrial activity also appears to be critical for synaptic maintenance. In mature hair cells, activity evoked mitochondrial $\mathrm{Ca}^{2+}$ uptake functions to sustain presynaptic $\mathrm{Ca}^{2+}$ responses and maintain synapse integrity. Blocking mitochondrial $\mathrm{Ca}^{2+}$ uptake by treating with $\mathrm{Ru} 360$ or the voltage-dependent anion channel (VDAC) inhibitor TRO 19622 impaired presynaptic $\mathrm{Ca}^{2+}$ signals (Wong et al., 2019). In addition, partially blocking mitochondrial $\mathrm{Ca}^{2+}$ uptake with a low dose of Ru360 led to a high density of presynaptic $\mathrm{Ca}_{V} 1.3$ channel clusters, while completely blocking MCU with a high dose of Ru360 led to increased synaptic ribbon size and a reduction in the number of synapses per hair cell. These data establish a role of presynaptic $\mathrm{Ca}^{2+}$ signaling in the maintenance of hair-cell ribbon synapses. It is likely that this process occurs via a mitochondrial mechanism, as inhibition of mitochondrial $\mathrm{Ca}^{2+}$ uptake with Ru360 did not affect cytosolic $\mathrm{Ca}^{2+}$ concentrations, while modulation of $\mathrm{Ca}_{V} 1.3$ with isradipine or Bay K8644 resulted in changes in mitochondrial $\mathrm{Ca}^{2+}$ levels (Wong et al., 2019).

In conjunction with the mitochondrion, the endoplasmic reticulum (ER) is also a critical regulator of $\mathrm{Ca}^{2+}$ signaling within the cell (Schwarz and Blower, 2016). These two organelles are associated with mitochondrial associated membranes (MAMs), and $\mathrm{Ca}^{2+}$ transfer between them has been implicated in a wide range of cellular processes, including bioenergetics and cell death (Vance, 1990; Rizzuto et al., 2009; Bravo et al., 2012; Giorgi et al., 2012; Grimm, 2012). In zebrafish lateralline hair cells, it has been demonstrated that mitochondria buffer $\mathrm{Ca}^{2+}$ released from the ER (Esterberg et al., 2014). 

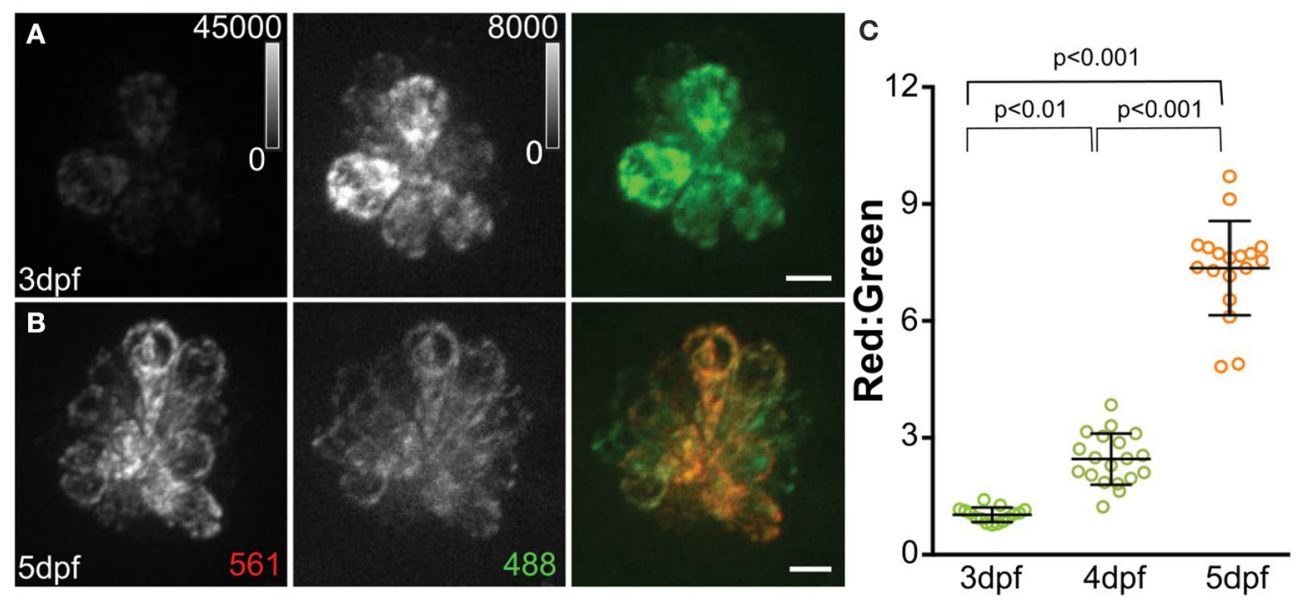

FIGURE 2 | MitoTimer fluorescence in hair cells. (A, B) Maximum-intensity projections of hair cells from Tg[myo6b:mitoTimer]w208 fish at 3dpf (A) and 5dpf (B). (C) Mean mitoTimer fluorescence plotted as ratio of red:green at 3, 4, and 5 dpf. Scale bar, $5 \mu \mathrm{m}$. Reproduced with permission from Pickett et al. (2018).

Using a mitochondrial matrix-targeted $\mathrm{Ca}^{2+}$ indicator GCaMP3 (mitoGCaMP3), they observed increased fluorescence, indicative of increased local $\mathrm{Ca}^{2+}$ concentration, upon activation of inositol trisphosphate receptors ( $\mathrm{IP}_{3} \mathrm{Rs}$ ) with adenophostin $\mathrm{A}$, and decreased GCaMP fluorescence upon inhibition of $\mathrm{IP}_{3} \mathrm{Rs}$ with xestospongin $\mathrm{C}$ or by blocking the $\mathrm{MCU}$ with Ru360. $\mathrm{IP}_{3} \mathrm{Rs}$ in the $\mathrm{ER}$ are involved in $\mathrm{Ca}^{2+}$ release into the cytosol and are coupled with mitochondrial VDAC in MAMs (Szabadkai et al., 2006). Thus, the observed changes in mitochondrial $\mathrm{Ca}^{2+}$ upon modulation of $\mathrm{IP}_{3} \mathrm{Rs}$ support the flow of $\mathrm{Ca}^{2+}$ from the ER to the mitochondria (Esterberg et al., 2014). It has been previously suggested that $\mathrm{Ca}^{2+}$ originating in the ER is first transferred to the cytosol before being taken up by mitochondria (Patergnani et al., 2011). To simultaneously monitor cytoplasmic and mitochondrial $\mathrm{Ca}^{2+}$ dynamics in the same cell, Esterberg et al. (2014) combined mitoGCaMP3 with the red cytosolic $\mathrm{Ca}^{2+}$ indicator RGECO and found that transient increases in cytosolic RGECO fluorescence corresponded with mitochondrial GCaMP3 increases. Upon ER modulation with adenophostin A, they observed increases in both cytosolic and mitochondrial $\mathrm{Ca}^{2+}$, but upon treatment with thapsigargin, only an increase in mitochondrial $\mathrm{Ca}^{2+}$ was observed. Further, by using local uncaging of photolabile EGTA preloaded with $\mathrm{Ca}^{2+}$ (caEGTA) to transiently elevate intracellular $\mathrm{Ca}^{2+}$ levels, they observed increased mitochondrial $\mathrm{Ca}^{2+}$ uptake that corresponded with an increase in mitochondrial transmembrane potential $\left(\Delta \Psi_{\mathrm{m}}\right)$, suggesting that even transient increases in mitochondrial $\mathrm{Ca}^{2+}$ can affect mitochondrial activity in hair cells. Cumulatively, these results show that under nonpathological conditions mitochondria take up $\mathrm{Ca}^{2+}$ released from the ER and that changes in mitochondrial $\mathrm{Ca}^{2+}$ can alter mitochondrial activity.

A recent study defined the short- and long-term consequences of evoked hair-cell activity on mitochondrial function. Using the same cytosolic and mitochondrial $\mathrm{Ca}^{2+}$ indicators described earlier, Pickett et al. (2018) observed increases in both cytosolic and mitochondrial $\mathrm{Ca}^{2+}$ in response to acute stimulation of hair cells, i.e., directional displacement of hair-cell stereocilia via a waterjet. Notably, the two evoked $\mathrm{Ca}^{2+}$ signals showed different kinetics, with rapid onset and decay in cytosolic $\mathrm{Ca}^{2+}$ signal followed by a slower rise and longer decay in mitochondrial $\mathrm{Ca}^{2+}$ signal. Mutants lacking mechanotransduction showed a reduced mitochondrial transmembrane potential, indicating reduced mitochondrial activity in the absence of hair-cell activity. To define long-term consequences on mitochondrial function, they next examined how cumulative hair-cell activity influenced the state of mitochondria using MitoTimer, a genetically encoded indicator of mitochondrial oxidation. Newly synthesized MitoTimer fluoresces green, but irreversibly shifts to red upon dehydrogenization of the Tyr-67 residue (Figure 2). Sustained lateral-line hair-cell stimulation in larvae exposed to $24 \mathrm{~h}$ of water currents generated by orbital rotation resulted in significantly increased MitoTimer fluorescence ratio that corresponded with increased hair-cell ROS, as measured with cellROX (a probe for oxidative stress; Table 1), and was dependent on hair-cell MET. Increased MitoTimer fluorescence also occurred with age; older hair cells had a higher red:green MitoTimer ratio compared with younger hair cells. These data support that hair-cell activity influences cumulative mitochondrial activity and hair-cell oxidation.

\section{MITOCHONDRIA IN RESPONSE TO AMINOGLYCOSIDE OTOTOXICITY}

Aminoglycoside antibiotics, such as neomycin and gentamicin, are widely used to treat Gram-negative bacterial infections, such as tuberculosis (Forge and Schacht, 2000). These drugs also cause hearing loss in up to $20 \%$ of patients who take them, and this hearing loss is due to aminoglycoside-mediated hair-cell death (Xie et al., 2011). While it is known that aminoglycosides function by binding to ribosomal subunits and interfering with bacterial translation, the mechanisms underlying hair-cell death were still unclear (Borovinskaya et al., 2007, 2008). Further, 
TABLE 1 | Drugs, vital dyes, and indicators used to study hair-cell mitochondrial biology.

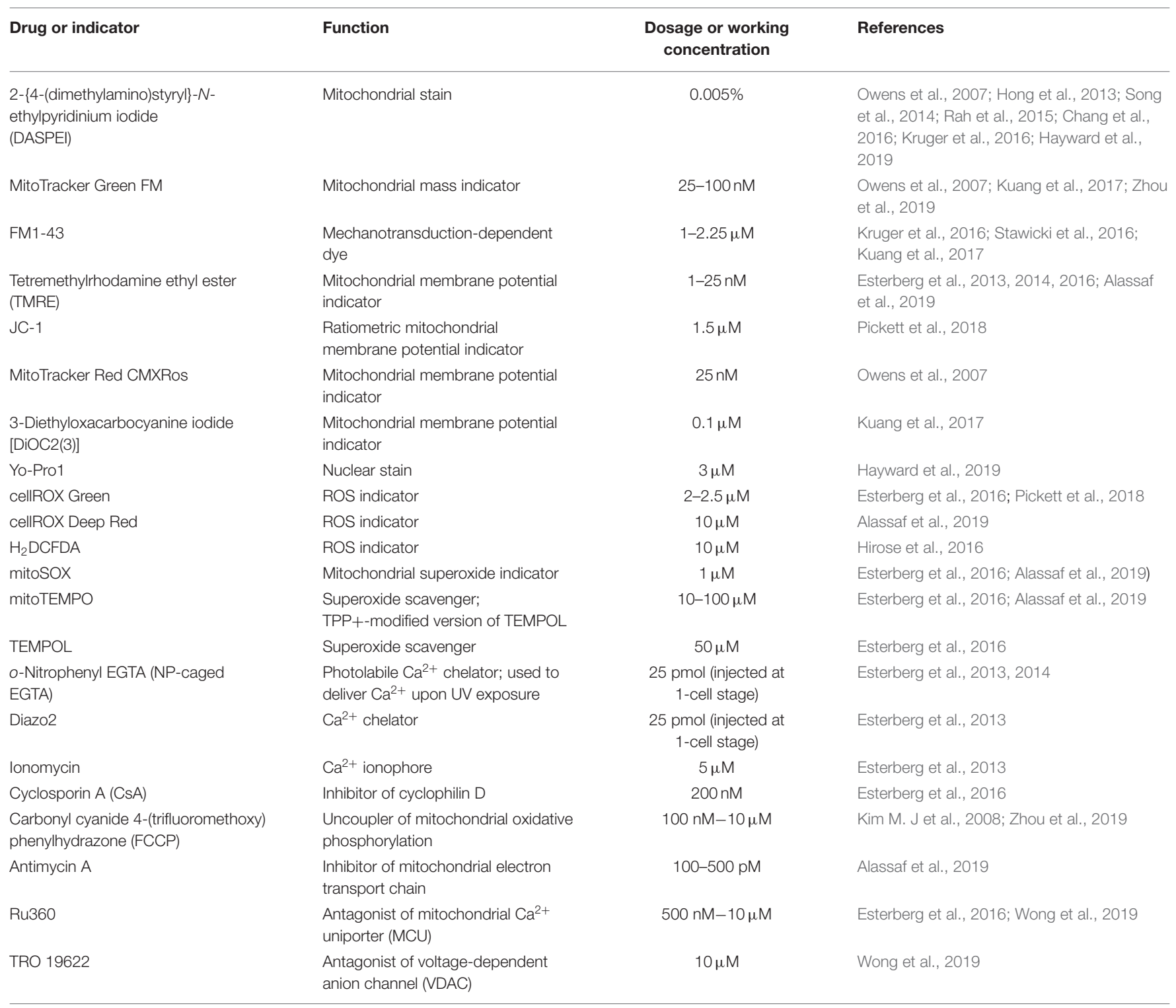

there is evidence that different aminoglycosides kill hair cells by different pathways (Coffin et al., 2013b). There is thus a need to understand the various mechanisms of ototoxic damage by aminoglycosides to prevent loss of hair cells. In addition, it has been demonstrated that the mitochondrial ribosome closely resembles the prokaryotic ribosome, suggesting a role of mitochondria in the response to aminoglycosides (Lynch and Puglisi, 2001).

Neomycin has been widely used to study ototoxic effects in the zebrafish lateral line, and an early analysis of the hair-cell ultrastructure in response to neomycin demonstrated mitochondrial swelling that preceded other cellular phenotypes (Owens et al., 2007). More recent work has shown that a hair cell's history of mitochondrial activity can predict its susceptibility to neomycin-induced death, such that hair cells with more cumulative mitochondrial activity, including hair cells that are older, are more vulnerable to aminoglycoside-induced death (Pickett et al., 2018).

As mitochondria play a critical role in regulating intracellular $\mathrm{Ca}^{2+}$, recent studies have sought to characterize mitochondrial $\mathrm{Ca}^{2+}$ dynamics in the context of neomycin-induced haircell damage. In dying hair cells exposed to neomycin, the mitochondrial potential $\left(\Delta \Psi_{\mathrm{m}}\right)$ collapses, followed by a spike in cytosolic $\mathrm{Ca}^{2+}$ (Esterberg et al., 2013). Elevating intracellular $\mathrm{Ca}^{2+}$ by uncaging caEGTA resulted in haircell death and increased susceptibility to neomycin, while decreasing intracellular $\mathrm{Ca}^{2+}$ by uncaging the $\mathrm{Ca}^{2+}$ chelator diazo 2 exhibited a protective effect. In addition, it has been observed that both cytosolic $\mathrm{Ca}^{2+}$ and mitochondrial $\mathrm{Ca}^{2+}$ levels spike in dying hair cells exposed to neomycin (Esterberg et al., 2014). Inducing $\mathrm{Ca}^{2+}$ release from the ER by treatment with thapsigargin or activating $\mathrm{IP}_{3} \mathrm{Rs}$ with adenophostin $\mathrm{A}$ 


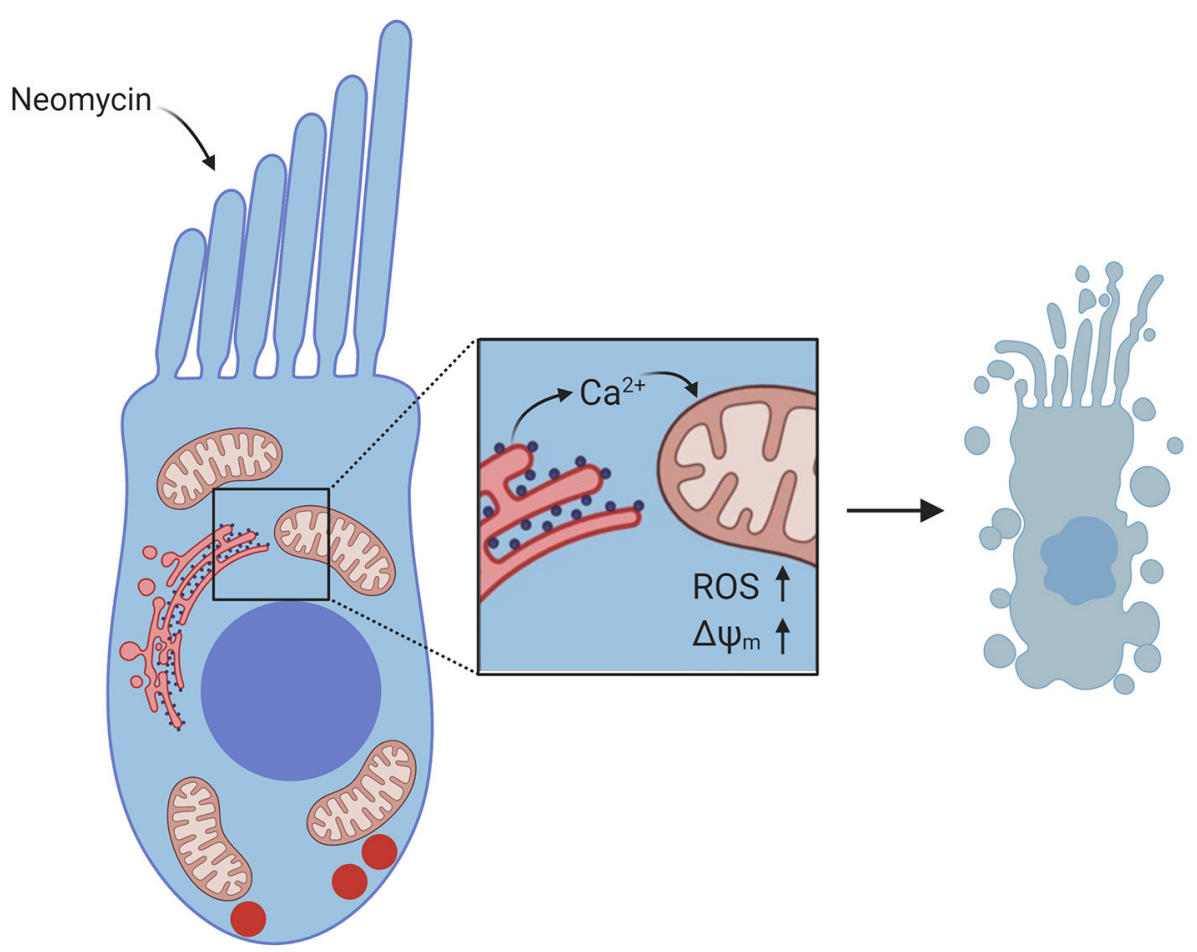

FIGURE 3 | Diagram of $\mathrm{Ca}^{2+}$ signaling in hair cells exposed to neomycin. Neomycin enters the hair cell through MET channels at the apex. Inset shows flow of Ca ${ }^{2+}$ from the ER to the mitochondria, resulting in increased ROS levels and increased $\Delta \Psi_{\mathrm{m}}$, which leads to hair-cell death. Created with BioRender.com.

increased neomycin-induced hair-cell death, while inhibiting $\mathrm{IP}_{3} \mathrm{Rs}$ with xestospongin $\mathrm{C}$ protected hair cells. Blocking mitochondrial $\mathrm{Ca}^{2+}$ uptake with Ru360 also protected hair cells, suggesting that the flow of $\mathrm{Ca}^{2+}$ from the ER to the mitochondria is a defining event in neomycin-induced hair-cell death. This $\mathrm{Ca}^{2+}$ transfer from the ER to the mitochondria drives increased mitochondrial hyperpolarization during hair-cell death (Figure 3). Further, modulating mitochondrial polarization altered hair-cell susceptibility to neomycin, such that increasing $\Delta \Psi_{\mathrm{m}}$ by treatment with cyclosporin $\mathrm{A}$ increased neomycin toxicity, while mitochondrial depolarization by treatment with FCCP protected hair cells from neomycin-induced death. These data provide a mechanism by which mitochondrial $\mathrm{Ca}^{2+}$ plays a key role in neomycin-induced hair-cell death.

While the mechanisms underlying neomycin-induced haircell death have been well researched, gentamicin ototoxicity has been relatively understudied in the zebrafish lateral line. It has been shown that the hair-cell signaling pathways activated in response to gentamicin and time course of haircell death are different from that of neomycin; it is thus important to understand the mechanisms of damage by different aminoglycosides to develop protective therapies (Owens et al., 2009; Coffin et al., 2013a,b; Wiedenhoft et al., 2017). While a requirement for caspases in aminoglycoside-induced hair-cell death has been established in vivo in chick and in vitro in mammalian inner ear cultures, a study in the zebrafish lateral line demonstrated that both neomycin and gentamicin induce hair-cell death by caspase-independent pathways, as treatment with the caspase inhibitor Z-VAD-Fmk did not confer protection against either aminoglycoside (Coffin et al., 2013b). One study defined the relative roles of p53 signaling in neomycin and gentamicin ototoxicity. In apoptosis, p53 rapidly translocates to the mitochondria, preceding other mitochondrial phenotypes such as changes in $\Delta \Psi_{\mathrm{m}}$ and release of cytochrome $c$ (Marchenko et al., 2000). In the mitochondria, p53 directly interacts with Bcl-2 to block its anti-apoptotic activity and induces apoptosis by interacting with pro-apoptotic proteins such as Bax (Mihara et al., 2003; Chipuk et al., 2004; Deng et al., 2006). Inhibition of the pro-apoptotic protein Bax offered some protection against neomycin- but not gentamicin-induced hair-cell loss, suggesting a Bax-dependent cell death pathway is involved in neomycin ototoxicity. In contrast, the p53 inhibitor pifithrin- $\alpha$ (PFT $\alpha)$ offered protection against gentamicin-induced hair-cell death suggesting an alternative, p53-dependent pathway underlying gentamicin ototoxicity. This is underscored by the observation that stabilizing p53 by treating with nutlin-3a, an inhibitor of the p53 antagonist Mdm2, sensitized hair cells to toxicity from chronic gentamicin exposure (Coffin et al., 2013a). In the same study, they found that overexpression of $\mathrm{Bcl} 2$, a target of p53, robustly protected zebrafish against gentamicininduced hair-cell loss, but that some hair-cell death occurred after the course of treatment, implying that delayed hair-cell death following continuous gentamicin treatment is independent of p53. Future studies profiling the pathways involved in aminoglycoside-induced hair-cell death and defining the roles of proteins such as p53 and Bax will be useful in identifying 
therapeutic targets to protect against aminoglycoside ototoxicity. In addition, it is important to consider the differences between model systems in response to aminoglycosides, such as the requirement for caspases.

While there are obvious differences between model organisms, such as the differences between zebrafish neuromasts and the mammalian cochlea, there may also be differences between strains of a single species. A recent study found that the Tupfel long-fin (TL) wild-type strain of zebrafish were less vulnerable to gentamicin-induced hair-cell loss than the $\mathrm{AB}^{*}$ strain of zebrafish (Wiedenhoft et al., 2017). Both of these strains of zebrafish are commonly used for a variety of studies, including studies of hair-cell biology. They observed that, while stabilizing p53 with nutlin-3a sensitized $\mathrm{AB}^{*}$ hair cells to gentamicin-induced death, nutlin-3a treatment did not affect the survival of TL hair cells exposed to gentamicin, suggesting there may be strain-specific differences in p53 signaling. It is thus important to also consider the strain of zebrafish in studies of hair-cell biology.

\section{MITOCHONDRIAL ROS PRODUCTION AND ANTIOXIDANT PROTECTION AGAINST ENVIRONMENTAL HAIR-CELL DAMAGE}

One consequence of oxidative phosphorylation is the generation of ROS. Mitochondrial ROS are generally produced in the form of superoxide or hydrogen peroxide due to oxidation of metabolic intermediates in the electron transport chain complexes I and III (Brand, 2016). Hydroxyl radicals can also be produced in the mitochondria by the Fenton reaction, in which iron compounds are reduced by superoxide (Thomas et al., 2009). Under homeostatic conditions, ROS production is tightly regulated. Under conditions of oxidative stress, however, cytosolic ROS can stimulate the further production of ROS, potentially leading to a cascade of oxidative damage to macromolecules within the cell (Kroller-Schon et al., 2014).

Mitochondrial ROS production may play a role in aminoglycoside ototoxicity. It has been shown that aminoglycosides bind to iron salts and stimulate the production of free radicals by Fenton chemistry (Priuska and Schacht, 1995; Kohanski et al., 2007). A study in zebrafish lateral line observed an increase in ROS levels, as measured by the indicator cellROX green and by the hydrogen peroxide biosensor HyPer, in dying hair cells upon neomycin exposure (Esterberg et al., 2016). The increased hydrogen peroxide level corresponded with increased $\Delta \Psi_{\mathrm{m}}$ and mitochondrial oxidation, as reflected by the indicator mitoSOX (Table 1). These observed phenotypes were driven by mitochondrial $\mathrm{Ca}^{2+}$ uptake; blocking entry of $\mathrm{Ca}^{2+}$ into the mitochondria with Ru360 reduced ROS levels and mitochondrial oxidation after neomycin exposure. Cumulatively, these data suggest that mitochondrial $\mathrm{Ca}^{2+}$ uptake is an event upstream of neomycin ototoxicity, with ROS playing an additional role.

Exogenous antioxidants have shown promising otoprotective effects in zebrafish lateral line and mammalian cochlear explants (Ton and Parng, 2005; Noack et al., 2017; Hur et al., 2018). However, this approach has had limited success in clinical trials, likely because different antioxidants act via distinct cellular targets and molecular pathways (Noack et al., 2017). While treatment with exogenous antioxidants or ROS scavengers is one potential approach to protect hair cells from ototoxicity, another strategy is to leverage endogenous mechanisms within cells to protect against damage by ROS. To guard against oxidative stress, organisms have developed endogenous defense mechanisms, including antioxidant enzymes such as catalase, glutathione peroxidase, superoxide dismutases, and heme oxygenase-1 (HO1) (Mates, 2000). Expression of these antioxidant enzymes can be induced by activators of peroxisome proliferator-activated receptor- $\alpha$ (PPAR- $\alpha$ ) (Toyama et al., 2004). Fenofibrate, one such PPAR- $\alpha$ agonist, offered modest protection against gentamicininduced hair-cell loss in both rat cochlear explants and in zebrafish lateral-line neuromasts (Park et al., 2017). This protection required activity of $\mathrm{HO}-1$, as inhibition of $\mathrm{HO}-1$ by SnPPIX abolished these protective effects. Thus, stimulating endogenous antioxidant pathways could also provide some protection against aminoglycoside-induced damage. Another approach to protecting against aminoglycoside ototoxicity is the use of ROS scavengers. Treatment of zebrafish with NecroX5, an ROS and RNS scavenger, offered modest protection against neomycin-induced damage (Song et al., 2014). NecroX5 exposure partially rescued neomycin-induced phenotypes including hair-cell loss, hair-cell apoptosis, and damage to hair bundles and hair-cell mitochondria. Treatment with quercetin, another ROS scavenger which has been shown to have antioxidant properties in vitro, also protected against neomycin-induced hair-cell loss (Hirose et al., 2016). Quercetin also reduced ROS levels, as detected by $\mathrm{H}_{2}$ DCFDA labeling (Table 1).

In mammals, it has been shown that ROS are generated in the cochlea after noise exposure, and that antioxidants administered before or after exposure can potentially ameliorate noise-induced damage (Yamane et al., 1995; Ohlemiller et al., 1999; Ohinata et al., 2000; Oishi and Schacht, 2011). A recent study sought to model severe noise damage in the zebrafish lateral line using an ultrasonic device to produce cavitation creating small localized shock waves, and found that exposure to this stimulus resulted in hair-cell death $48-72 \mathrm{~h}$ after exposure (Uribe et al., 2018). Treatment with the antioxidant D-methionine prevented this sonic-induced hair-cell loss, suggesting a role for oxidative stress in this model. Because zebrafish can be exposed to drugs by bath application, they are an optimal system in which to screen for protective or harmful drugs. By screening a redox library for compounds that protected against damage, glutathione, baicalein, $\mathrm{D}-\alpha$-tocopherylquinone, and ferulic acid ethylester were identified as protective agents (Uribe et al., 2018). As reducing oxidative stress gains attention as a strategy to prevent noise-induced hair-cell death, zebrafish models may provide information toward identifying effective protective therapeutic strategies.

It has been suggested, specifically in the context of aminoglycoside ototoxicity, that hair cells "find a way to die" such that inhibition of one death pathway will lead to the activation of other death pathways, and that it may be necessary to target multiple pathways to fully protect hair cells from ototoxins, such as by using drug cocktails or by using drugs that have 
multiple modes of action (Vandenabeele et al., 2006; Ou et al., 2012). It has been determined that aminoglycosides enter hair cells through MET channels, so one approach to protecting against aminoglycoside ototoxicity could be to block uptake through MET (Alharazneh et al., 2011; Hailey et al., 2017). In zebrafish, it has been shown that treatment with quinoline ring derivatives such as amsacrine, quinine, and mefloquine protects against aminoglycoside-induced hair-cell death by blocking uptake (Ou et al., 2012). Analogs of the quinoline ring derivative berbamine have also recently been shown to block uptake of aminoglycosides into hair cells; however, the degree of uptake block did not correlate with the magnitude of hair-cell protection from aminoglycosides, suggesting a second uptake-independent mechanism (Kruger et al., 2016; Hudson et al., 2020). Quinoline

TABLE 2 | Transgenic zebrafish lines used to visualize and study hair-cell mitochondrial dynamics.

\begin{tabular}{|c|c|c|}
\hline Transgene & Description & References \\
\hline Tg[myo6b:cytoRGECO] & $\begin{array}{l}\text { Hair-cell specific } \mathrm{Ca}^{2+} \\
\text { biosensor }\end{array}$ & Esterberg et al., 2014 \\
\hline Tg[myo6b:cytoGCaMP3] & $\begin{array}{l}\text { Hair-cell specific } \mathrm{Ca}^{2+} \\
\text { biosensor }\end{array}$ & Esterberg et al., 2013 \\
\hline Tg[myo6b:mitoRGECO] & $\begin{array}{l}\text { Mitochondrially localized } \\
\mathrm{Ca}^{2+} \text { biosensor in hair cells }\end{array}$ & Esterberg et al., 2014 \\
\hline Tg[myo6b:mitoGCaMP3] & $\begin{array}{l}\text { Mitochondrially localized } \\
\mathrm{Ca}^{2+} \text { biosensor in hair cells }\end{array}$ & Esterberg et al., 2014 \\
\hline Tg[myo6b:erGCaMP3] & $\begin{array}{l}\text { ER-localized } \mathrm{Ca}^{2+} \\
\text { biosensor in hair cells }\end{array}$ & Esterberg et al., 2014 \\
\hline $\begin{array}{l}\text { Tg[myo6b:GCaMP6s- } \\
\text { CAAX] }\end{array}$ & $\begin{array}{l}\text { Membrane-localized } \mathrm{Ca}^{2+} \\
\text { biosensor in hair cells }\end{array}$ & Jiang et al., 2017 \\
\hline Tg[myo6b:HyPer] & $\begin{array}{l}\text { Hair-cell specific hydrogen } \\
\text { peroxide biosensor }\end{array}$ & Esterberg et al., 2016 \\
\hline Tg[myo6b:Rex-YFP] & $\begin{array}{l}\mathrm{NAD}(\mathrm{H}) \text { redox fluorescent } \\
\text { indicator in hair cells }\end{array}$ & Wong et al., 2019 \\
\hline Tg[myo6b:mitoTimer] & $\begin{array}{l}\text { Mitochondrially localized } \\
\text { fluorescent indicator of } \\
\text { mitochondrial oxidation or } \\
\text { turnover in hair cells }\end{array}$ & Pickett et al., 2018 \\
\hline Tg[myo6b:mitoEos] & $\begin{array}{l}\text { Mitochondrially localized } \\
\text { photoconvertible } \\
\text { fluorophore in hair cells }\end{array}$ & Pickett et al., 2018 \\
\hline
\end{tabular}

ring derivatives have been shown to have antioxidant properties in other systems (Detsi et al., 2007; Naik et al., 2009; Ghinet et al., 2012). It would be interesting to know whether these compounds also function as antioxidants in a zebrafish or mammalian model of ototoxicity, as it will be important to identify drugs that could target both aminoglycoside uptake and oxidative stress in hair cells as candidate treatments for the prevention of aminoglycoside-induced hearing loss in humans.

\section{OXIDATIVE STRESS AND CISPLATIN}

Cisplatin is an anti-cancer chemotherapeutic drug that is commonly used to treat a number of different cancers. Notably, cisplatin treatment causes hearing loss in up to $80 \%$ of patients (Frisina et al., 2016). Cisplatin ototoxicity has been linked to ROS, in that ROS deplete cochlear tissue of antioxidants, leading to increased free radical production and subsequent lipid peroxidation (Rybak, 2007). In addition, cisplatin may induce hair-cell death, at least in part, by activating ROS-mediated cell death pathways in mitotically quiescent hair cells (Kim C. H et al., 2008). This mode of induction is in contrast to mitotically active cells, where cisplatin induces cell death through DNA damage and activation of apoptosis.

Similar to work with aminoglycosides, protection against cisplatin ototoxicity using antioxidants and ROS scavengers has been an intriguing topic of recent study. Epicatechin, a ROS scavenger derived from tea leaves, has been shown to protect zebrafish from cisplatin-induced lateral-line hair-cell loss (Kim C. H et al., 2008). Kenpaullone, an inhibitor of cyclindependent kinase 2, was shown to reduce ROS in cochlear explants and also protected against cisplatin-induced damage in the zebrafish lateral line (Teitz et al., 2018). Quercetin, similar to its effect on aminoglycoside ototoxicity, protected against cisplatin-induced hair-cell loss and mitochondrial damage (Lee et al., 2015). Finally, the free radical scavenger edaravone also showed a protective effect against cisplatin-induced hair-cell loss, mitochondrial damage, and damage to hair bundles (Hong et al., 2013). While it has been shown that cisplatin ototoxicity in the lateral line is both dose and time dependent (Ou et al., 2007), one notable deficit in the area of cisplatin ototoxicity research in zebrafish is a current lack of consistent cisplatin damage
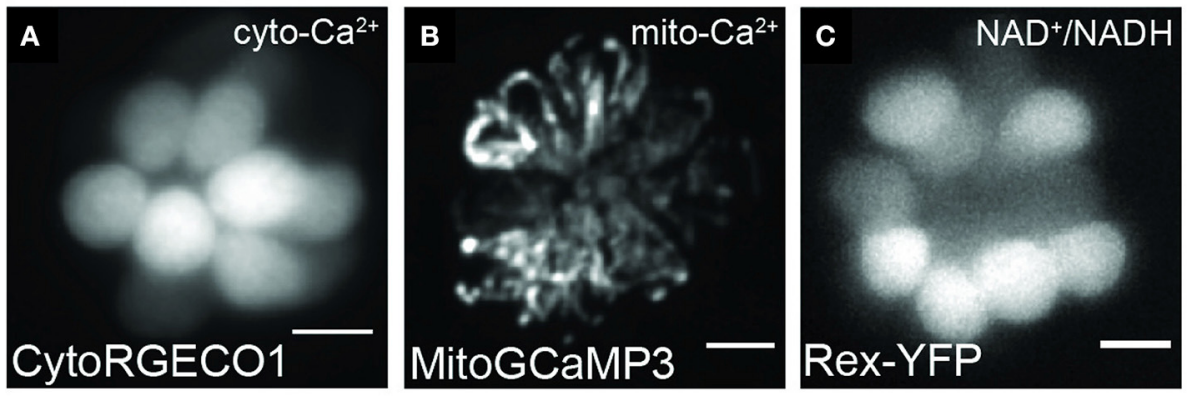

FIGURE 4 | Representative images of hair cells expressing transgenes used to visualize mitochondrial dynamics. Live hair cells expressing RGECO1 (A), MitoGCaMP3 (B), and Rex-YFP (C). Scale bar, 5 m. Adapted with permission from Wong et al. (2019). 
protocols, i.e., optimal dosage and time of exposure used across studies (Domarecka et al., 2020). As cisplatin acts as a cytotoxin through diverse cellular pathways, optimizing damage protocols in zebrafish will be required to determine the relative role of ROS accumulation in cisplatin ototoxicity.

\section{USING GENETIC TOOLS TO STUDY ZEBRAFISH HAIR-CELL MITOCHONDRIAL BIOLOGY}

While acquired hearing loss can be caused by exposure to noise or ototoxic drugs, some hearing loss is inherited (Lenz and Avraham, 2011; Mahboubi et al., 2012). In addition, susceptibility to age-related, noise-induced, or aminoglycosideinduced hearing loss may also have a genetic component. Recent whole-genome sequencing and genome-wide association studies have identified genes implicated in acquired hearing loss (Zhao et al., 2013; Lavinsky et al., 2015; Vuckovic et al., 2018; Nagtegaal et al., 2019; Wells et al., 2019). Interestingly, mitochondrial mutations have also been associated with hearing loss susceptibility (Jing et al., 2015). Identifying and studying both mitochondrial genes and genes involved in regulating mitochondrial function will undoubtedly aid in developing protective therapies.

Zebrafish have been a popular model for genetic studies due to their high fecundity and ease of genetic manipulation. Forward genetic screens in zebrafish have proven useful for identifying genes required for hearing and balance as well as in pathways involved in aminoglycoside-induced death (Nicolson et al., 1998; Owens et al., 2008; Stawicki et al., 2016; Nicolson, 2017). Through reverse genetics, using tools such as CRISPR/Cas9, one can generate mutations in zebrafish as a way to study those implicated in hearing loss in humans (Liu et al., 2019). In addition to generating mutations to study gene function, transgenic fluorescent reporters can also be used to visualize cellular and subcellular structures and dynamics (Table 2; Figure 4).

Forward genetic screens have been particularly useful for identifying novel gene function in the zebrafish lateral line. One such gene identified using forward genetics is pappaa, which encodes pregnancy-associated plasma protein-aa (Wolman et al., 2015). Pappaa acts in the IGF1 signaling pathway and has recently been shown to regulate hair-cell mitochondrial function (Alassaf et al., 2019). pappaa ${ }^{p 170}$ mutant zebrafish were more susceptible to neomycin-induced hair-cell death and had elevated ROS levels in their hair cells. In addition, pappaa ${ }^{p 170}$ mutant hair cells had increased mitochondrial $\mathrm{Ca}^{2+}$, hyperpolarized $\Delta \Psi_{\mathrm{m}}$, and reduced expression of the mitochondrial antioxidant genes $g p x$, sod1, and $\operatorname{sod} 2$, all of which could contribute to increased ROS levels. Treatment with the ROS scavenger mitoTEMPO rescued

\section{REFERENCES}

Alassaf, M., Daykin, E. C., Mathiaparanam, J., and Wolman, M. A. (2019). Pregnancy-associated plasma protein-aa supports hair cell survival by regulating mitochondrial function. Elife 8:e47061. doi: 10.7554/eLife.470 61.033 pappaa $^{\text {p170 }}$ mutant susceptibility to neomycin-induced hair-cell death, suggesting that elevated ROS underlies the enhanced haircell death in pappaa ${ }^{p 170}$ mutants. The study supports the utility of zebrafish forward genetic screens in identifying novel genes involved in mitochondrial function and hair-cell vulnerability.

Another study used CRISPR/Cas9 technology to delete the gene mtu1 to study its function in hair cells (Zhang et al., 2018). This gene encodes a highly conserved mitochondrial tRNA modifying enzyme. In humans, deficient tRNA modification is associated with deafness (Wang et al., 2016). mtu1deficient zebrafish had deficient thiolation of mitochondrial tRNA, as well as decreased levels of mitochondrial tRNA and mitochondrial proteins (Zhang et al., 2018). $m t u 1^{-/-}$ zebrafish also had deficient oxidative phosphorylation and reduced ATP. In the lateral line, $m t u 1^{-/-}$zebrafish had fewer hair cells per neuromast. These results support a role for mitochondrial tRNA modification in deafness and demonstrate the value in using reverse genetics to study gene function in hair cells.

\section{CONCLUSION}

The zebrafish lateral line is a valuable model system in which to study hair-cell mitochondria and offers unique tools such as the ability to visualize mitochondrial dynamics in vivo. Studies utilizing this system have shed light on the roles of mitochondria in calcium homeostasis and synapse regulation as well as supported roles of mitochondria in cell death pathways, particularly in response to ototoxic drugs like aminoglycosides. The strides made from zebrafish studies contribute to the understanding of hearing loss in humans and will lead to development of preventative or protective therapies in the future.

\section{AUTHOR CONTRIBUTIONS}

$\mathrm{MH}$ and LS wrote the manuscript. All authors contributed to the article and approved the submitted version.

\section{FUNDING}

This work was supported by NIH/NIDCD Grant R01-DC016066 (LS) and by the Washington University School of Medicine Department of Otolaryngology-Head \& Neck Surgery.

\section{ACKNOWLEDGMENTS}

We thank Angela Schrader and Allison Saettele for their comments on the article.

Alharazneh, A., Luk, L., Huth, M., Monfared, A., Steyger, P. S., Cheng, A. G., et al. (2011). Functional hair cell mechanotransducer channels are required for aminoglycoside ototoxicity. PLoS ONE 6:e22347. doi: 10.1371/journal.pone.0022347

Ashkenazi, A. (2002). Targeting death and decoy receptors of the tumour-necrosis factor superfamily. Nat. Rev. Cancer 2, 420-430. doi: 10.1038/nrc821 
Balak, K. J., Corwin, J. T., and Jones, J. E. (1990). Regenerated hair cells can originate from supporting cell progeny: evidence from phototoxicity and laser ablation experiments in the lateral line system. J. Neurosci. 10, 2502-2512. doi: 10.1523/JNEUROSCI.10-08-02502.1990

Berridge, M. J., Bootman, M. D., and Roderick, H. L. (2003). Calcium signalling: dynamics, homeostasis and remodelling. Nat. Rev. Mol. Cell. Biol. 4, 517-529. doi: $10.1038 / \mathrm{nrm} 1155$

Bock, F. J., and Tait, S. W. G. (2020). Mitochondria as multifaceted regulators of cell death. Nat. Rev. Mol. Cell Biol. 21, 85-100. doi: 10.1038/s41580-019-0173-8

Borovinskaya, M. A., Pai, R. D., Zhang, W., Schuwirth, B. S., Holton, J. M., Hirokawa, G., et al. (2007). Structural basis for aminoglycoside inhibition of bacterial ribosome recycling. Nat. Struct. Mol. Biol. 14, 727-732. doi: $10.1038 / \mathrm{nsmb} 1271$

Borovinskaya, M. A., Shoji, S., Fredrick, K., and Cate, J. H. (2008). Structural basis for hygromycin B inhibition of protein biosynthesis. RNA 14, 1590-1599. doi: 10.1261/rna.1076908

Bottger, E. C., and Schacht, J. (2013). The mitochondrion: a perpetrator of acquired hearing loss. Hear. Res. 303, 12-19. doi: 10.1016/j.heares.2013.01.006

Brand, M. D. (2016). Mitochondrial generation of superoxide and hydrogen peroxide as the source of mitochondrial redox signaling. Free Radic. Biol. Med. 100, 14-31. doi: 10.1016/j.freeradbiomed.2016.04.001

Brandt, A., Striessnig, J., and Moser, T. (2003). CaV1.3 channels are essential for development and presynaptic activity of cochlear inner hair cells. J. Neurosci. 23, 10832-10840. doi: 10.1523/JNEUROSCI.23-34-10832.2003

Bravo, R., Gutierrez, T., Paredes, F., Gatica, D., Rodriguez, A. E., Pedrozo, Z., et al. (2012). Endoplasmic reticulum: ER stress regulates mitochondrial bioenergetics. Int. J. Biochem. Cell Biol. 44, 16-20. doi: 10.1016/j.biocel.2011.10.012

Chang, J., Choi, J., Rah, Y. C., Yoo, M. H., Oh, K. H., Im, G. J., et al. (2016). Sodium selenite acts as an otoprotectant against neomycin-induced hair cell damage in a zebrafish model. PLoS ONE 11:e0151557. doi: 10.1371/journal.pone.0151557

Chen, Y., Azad, M. B., and Gibson, S. B. (2009). Superoxide is the major reactive oxygen species regulating autophagy. Cell Death Differ. 16, 1040-1052. doi: $10.1038 /$ cdd.2009.49

Chipuk, J. E., Kuwana, T., Bouchier-Hayes, L., Droin, N. M., Newmeyer, D. D., Schuler, M., et al. (2004). Direct activation of Bax by p53 mediates mitochondrial membrane permeabilization and apoptosis. Science 303, 1010-1014. doi: 10.1126/science.1092734

Coffin, A. B., Rubel, E. W., and Raible, D. W. (2013a). Bax, Bcl2, and p53 differentially regulate neomycin- and gentamicin-induced hair cell death in the zebrafish lateral line. J. Assoc. Res. Otolaryngol. 14, 645-659. doi: 10.1007/s10162-013-0404-1

Coffin, A. B., Williamson, K. L., Mamiya, A., Raible, D. W., and Rubel, E. W. (2013b). Profiling drug-induced cell death pathways in the zebrafish lateral line. Apoptosis 18, 393-408. doi: 10.1007/s10495-013-0816-8

Collins, Y., Chouchani, E. T., James, A. M., Menger, K. E., Cocheme, H. M., and Murphy, M. P. (2012). Mitochondrial redox signalling at a glance. J. Cell Sci. 125 (Pt 4), 801-806. doi: 10.1242/jcs.098475

Deng, X., Gao, F., Flagg, T., Anderson, J., and May, W. S. (2006). Bcl2's flexible loop domain regulates 553 binding and survival. Mol. Cell. Biol. 26, 4421-4434. doi: 10.1128/MCB.01647-05

Detsi, A., Bouloumbasi, D., Prousis, K. C., Koufaki, M., Athanasellis, G., Melagraki, G., et al. (2007). Design and synthesis of novel quinolinone-3-aminoamides and their alpha-lipoic acid adducts as antioxidant and anti-inflammatory agents. J. Med. Chem. 50, 2450-2458. doi: 10.1021/jm061173n

Dijkgraaf, S. (1963). The functioning and significance of the lateral-line organs. Biol. Rev. Camb. Philos. Soc. 38, 51-105. doi: 10.1111/j.1469-185X.1963.tb00654.x

Domarecka, E., Skarzynska, M., Szczepek, A. J., and Hatzopoulos, S. (2020). Use of zebrafish larvae lateral line to study protection against cisplatininduced ototoxicity: a scoping review. Int. J. Immunopathol. Pharmacol. 34:2058738420959554. doi: 10.1177/2058738420959554

Du, C., Fang, M., Li, Y., Li, L., and Wang, X. (2000). Smac, a mitochondrial protein that promotes cytochrome c-dependent caspase activation by eliminating IAP inhibition. Cell 102, 33-42. doi: 10.1016/S0092-8674(00)00 008-8

Eckrich, T., Blum, K., Milenkovic, I., and Engel, J. (2018). Fast Ca(2+) transients of inner hair cells arise coupled and uncoupled to $\mathrm{Ca}(2+)$ waves of inner supporting cells in the developing mouse cochlea. Front. Mol. Neurosci. 11:264. doi: 10.3389/fnmol.2018.00264

Esterberg, R., Hailey, D. W., Coffin, A. B., Raible, D. W., and Rubel, E. W. (2013). Disruption of intracellular calcium regulation is integral to aminoglycoside-induced hair cell death. J. Neurosci. 33, 7513-7525. doi: 10.1523/JNEUROSCI.4559-12.2013

Esterberg, R., Hailey, D. W., Rubel, E. W., and Raible, D. W. (2014). ER-mitochondrial calcium flow underlies vulnerability of mechanosensory hair cells to damage. J. Neurosci. 34, 9703-9719. doi: 10.1523/JNEUROSCI.0281-14.2014

Esterberg, R., Linbo, T., Pickett, S. B., Wu, P., Ou, H. C., Rubel, E. W., et al. (2016). Mitochondrial calcium uptake underlies ROS generation during aminoglycoside-induced hair cell death. J. Clin. Invest. 126, 3556-3566. doi: 10.1172/JCI84939

Fettiplace, R. (2017). Hair cell transduction, tuning, and synaptic transmission in the mammalian cochlea. Compr. Physiol. 7, 1197-1227. doi: $10.1002 /$ cphy.c160049

Forge, A., and Schacht, J. (2000). Aminoglycoside antibiotics. Audiol. Neurootol. 5, 3-22. doi: 10.1159/000013861

Frank, T., Rutherford, M. A., Strenzke, N., Neef, A., Pangrsic, T., Khimich, D., et al. (2010). Bassoon and the synaptic ribbon organize $\mathrm{Ca}(2)+$ channels and vesicles to add release sites and promote refilling. Neuron 68, 724-738. doi: 10.1016/j.neuron.2010.10.027

Frisina, R. D., Wheeler, H. E., Fossa, S. D., Kerns, S. L., Fung, C., Sesso, H. D., et al. B. (2016). Comprehensive audiometric analysis of hearing impairment and tinnitus after cisplatin-based chemotherapy in survivors of adult-onset cancer. J. Clin. Oncol. 34, 2712-2720. doi: 10.1200/JCO.2016.66.8822

Ghinet, A., Farce, A., Oudir, S., Pommery, J., Vamecq, J., Henichart, J. P., et al. (2012). Antioxidant activity of new benzo[de]quinolines and lactams: 2D-quantitative structure-activity relationships. Med. Chem. 8, 942-946. doi: $10.2174 / 157340612802084216$

Giorgi, C., Baldassari, F., Bononi, A., Bonora, M., De Marchi, E., Marchi, S. et al. (2012). Mitochondrial $\mathrm{Ca}(2+)$ and apoptosis. Cell Calcium 52, 36-43. doi: 10.1016/j.ceca.2012.02.008

Goman, A. M., and Lin, F. R. (2016). Prevalence of hearing loss by severity in the United States. Am. J. Public Health 106, 1820-1822. doi: 10.2105/AJPH.2016.303299

Grimm, S. (2012). The ER-mitochondria interface: the social network of cell death. Biochim. Biophys. Acta 1823, 327-334. doi: 10.1016/j.bbamcr.2011.11.018

Hackney, C. M., Mahendrasingam, S., Penn, A., and Fettiplace, R. (2005). The concentrations of calcium buffering proteins in mammalian cochlear hair cells. I. Neurosci. 25, 7867-7875. doi: 10.1523/JNEUROSCI.1196-05.2005

Hailey, D. W., Esterberg, R., Linbo, T. H., Rubel, E. W., and Raible, D. W. (2017). Fluorescent aminoglycosides reveal intracellular trafficking routes in mechanosensory hair cells. J. Clin. Invest. 127, 472-486. doi: 10.1172/JCI 85052

Hayward, T., Young, A., Jiang, A., Crespi, E. J., and Coffin, A. B. (2019). Glucococorticoid receptor activation exacerbates aminoglycosideinduced damage to the zebrafish lateral line. Hear. Res. 377, 12-23. doi: 10.1016/j.heares.2019.03.002

Hirose, Y., Sugahara, K., Kanagawa, E., Takemoto, Y., Hashimoto, M., and Yamashita, H. (2016). Quercetin protects against hair cell loss in the zebrafish lateral line and guinea pig cochlea. Hear. Res. 342, 80-85. doi: 10.1016/j.heares.2016.10.001

Hong, S. J., Im, G. J., Chang, J., Chae, S. W., Lee, S. H., Kwon, S. Y., et al. (2013). Protective effects of edaravone against cisplatin-induced hair cell damage in zebrafish. Int. J. Pediatr. Otorhinolaryngol. 77, 1025-1031. doi: 10.1016/j.ijporl.2013.04.003

Hudson, A. M., Lockard, G. M., Namjoshi, O. A., Wilson, J. W., Kindt, K. S., Blough, B. E., et al. (2020). Berbamine analogs exhibit differential protective effects from aminoglycoside-induced hair cell death. Front. Cell. Neurosci. 14:234. doi: $10.3389 /$ fncel.2020.00234

Hur, D. G., Kurabi, A., and Ryan, A. F. (2018). Screening antioxidants for the protection of cochlear sensory cells. Neural Regen. Res. 13, 62-64. doi: $10.4103 / 1673-5374.224371$

Jensen-Smith, H. C., Hallworth, R., and Nichols, M. G. (2012). Gentamicin rapidly inhibits mitochondrial metabolism in high-frequency cochlear outer hair cells. PLoS ONE 7:e38471. doi: 10.1371/journal.pone.0038471 
Jiang, T., Kindt, K., and Wu, D. K. (2017). Transcription factor Emx2 controls stereociliary bundle orientation of sensory hair cells. Elife 6:e23661. doi: $10.7554 /$ eLife.23661.030

Jing, W., Zongjie, H., Denggang, F., Na, H., Bin, Z., Aifen, Z., et al. (2015). Mitochondrial mutations associated with aminoglycoside ototoxicity and hearing loss susceptibility identified by meta-analysis. J. Med. Genet. 52, 95-103. doi: 10.1136/jmedgenet-2014-102753

Johri, A., and Beal, M. F. (2012). Mitochondrial dysfunction in neurodegenerative diseases. J. Pharmacol. Exp. Ther. 342, 619-630. doi: 10.1124/jpet.112.192138

Kim, C. H., Kang, S. U., Pyun, J., Lee, M. H., Hwang, H. S., and Lee, H. (2008). Epicatechin protects auditory cells against cisplatin-induced death. Apoptosis 13, 1184-1194. doi: 10.1007/s10495-008-0242-5

Kim, M. J., Kang, K. H., Kim, C. H., and Choi, S. Y. (2008). Real-time imaging of mitochondria in transgenic zebrafish expressing mitochondrially targeted GFP. Biotechniques 45, 331-334. doi: 10.2144/000112909

Kindt, K. S., and Sheets, L. (2018). Transmission disrupted: modeling auditory synaptopathy in zebrafish. Front. Cell Dev. Biol. 6:114. doi: $10.3389 /$ fcell.2018.00114

Kohanski, M. A., Dwyer, D. J., Hayete, B., Lawrence, C. A., and Collins, J. J. (2007). A common mechanism of cellular death induced by bactericidal antibiotics. Cell 130, 797-810. doi: 10.1016/j.cell.2007.06.049

Kroller-Schon, S., Steven, S., Kossmann, S., Scholz, A., Daub, S., Oelze, M., et al. (2014). Molecular mechanisms of the crosstalk between mitochondria and NADPH oxidase through reactive oxygen species-studies in white blood cells and in animal models. Antioxid. Redox Signal. 20, 247-266. doi: 10.1089/ars.2012.4953

Kruger, M., Boney, R., Ordoobadi, A. J., Sommers, T. F., Trapani, J. G., and Coffin, A. B. (2016). Natural bizbenzoquinoline derivatives protect zebrafish lateral line sensory hair cells from aminoglycoside toxicity. Front. Cell. Neurosci. 10:83. doi: $10.3389 /$ fncel.2016.00083

Kuang, X., Zhou, S., Guo, W., Wang, Z., Sun, Y., and Liu, H. (2017). SS-31 peptide enables mitochondrial targeting drug delivery: a promising therapeutic alteration to prevent hair cell damage from aminoglycosides. Drug Deliv. 24, 1750-1761. doi: 10.1080/10717544.2017.1402220

Lanvers-Kaminsky, C., Zehnhoff-Dinnesen, A. A., Parfitt, R., and Ciarimboli, G. (2017). Drug-induced ototoxicity: mechanisms, pharmacogenetics, and protective strategies. Clin. Pharmacol. Ther. 101, 491-500. doi: 10.1002/cpt.603

Lavinsky, J., Crow, A. L., Pan, C., Wang, J., Aaron, K. A., Ho, M. K., et al. (2015). Genome-wide association study identifies nox3 as a critical gene for susceptibility to noise-induced hearing loss. PLoS Genet. 11:e1005094. doi: 10.1371/journal.pgen.1005094

Lee, S. K., Oh, K. H., Chung, A. Y., Park, H. C., Lee, S. H., Kwon, S. Y., et al. (2015). Protective role of quercetin against cisplatin-induced hair cell damage in zebrafish embryos. Hum. Exp. Toxicol. 34, 1043-1052. doi: 10.1177/0960327114567766

Lenz, D. R., and Avraham, K. B. (2011). Hereditary hearing loss: from human mutation to mechanism. Hear. Res. 281, 3-10. doi: 10.1016/j.heares.2011.05.021

Liochev, S. I. (2013). Reactive oxygen species and the free radical theory of aging. Free Radic. Biol. Med. 60, 1-4. doi: 10.1016/j.freeradbiomed.2013.02.011

Liu, K., Petree, C., Requena, T., Varshney, P., and Varshney, G. K. (2019). Expanding the CRISPR toolbox in zebrafish for studying development and disease. Front. Cell Dev. Biol. 7:13. doi: 10.3389/fcell.2019.00013

Liu, X., Kim, C. N., Yang, J., Jemmerson, R., and Wang, X. (1996). Induction of apoptotic program in cell-free extracts: requirement for dATP and cytochrome c. Cell 86, 147-157. doi: 10.1016/S0092-8674(00)80085-9

Lombarte, A., Yan, H. Y., Popper, A. N., Chang, J. S., and Platt, C. (1993). Damage and regeneration of hair cell ciliary bundles in a fish ear following treatment with gentamicin. Hear. Res. 64, 166-174. doi: 10.1016/0378-5955(93)90002-I

Lv, C., Stewart, W. J., Akanyeti, O., Frederick, C., Zhu, J., Santos-Sacchi, J., et al. (2016). Synaptic ribbons require ribeye for electron density, proper synaptic localization, and recruitment of calcium channels. Cell Rep. 15, 2784-2795. doi: 10.1016/j.celrep.2016.05.045

Lynch, S. R., and Puglisi, J. D. (2001). Structural origins of aminoglycoside specificity for prokaryotic ribosomes. J. Mol. Biol. 306, 1037-1058. doi: $10.1006 / j m b i .2000 .4420$

Magupalli, V. G., Schwarz, K., Alpadi, K., Natarajan, S., Seigel, G. M., and Schmitz, F. (2008). Multiple RIBEYE-RIBEYE interactions create a dynamic scaffold for the formation of synaptic ribbons. J. Neurosci. 28, 7954-7967. doi: 10.1523/JNEUROSCI.1964-08.2008

Mahboubi, H., Dwabe, S., Fradkin, M., Kimonis, V., and Djalilian, H. R. (2012). Genetics of hearing loss: where are we standing now? Eur. Arch. Otorhinolaryngol. 269, 1733-1745. doi: 10.1007/s00405-011-1910-6

Mammano, F., Bortolozzi, M., Ortolano, S., and Anselmi, F. (2007). Ca2+ signaling in the inner ear. Physiology 22, 131-144. doi: 10.1152/physiol.00040.2006

Marchenko, N. D., Zaika, A., and Moll, U. M. (2000). Death signal-induced localization of $\mathrm{p} 53$ protein to mitochondria. A potential role in apoptotic signaling. J. Biol. Chem. 275, 16202-16212. doi: 10.1074/jbc.275.21.16202

Marcotti, W., Johnson, S. L., Rusch, A., and Kros, C. J. (2003). Sodium and calcium currents shape action potentials in immature mouse inner hair cells. J. Physiol. 552 (Pt 3), 743-761. doi: 10.1113/jphysiol.2003.043612

Mates, J. M. (2000). Effects of antioxidant enzymes in the molecular control of reactive oxygen species toxicology. Toxicology 153, 83-104. doi: 10.1016/S0300-483X(00)00306-1

Matlib, M. A., Zhou, Z., Knight, S., Ahmed, S., Choi, K. M., Krause-Bauer, J., et al. (1998). Oxygen-bridged dinuclear ruthenium amine complex specifically inhibits $\mathrm{Ca} 2+$ uptake into mitochondria in vitro and in situ in single cardiac myocytes. J. Biol. Chem. 273, 10223-10231. doi: 10.1074/jbc.273.17.10223

McGrath, J., Roy, P., and Perrin, B. J. (2017). Stereocilia morphogenesis and maintenance through regulation of actin stability. Semin. Cell Dev. Biol. 65, 88-95. doi: 10.1016/j.semcdb.2016.08.017

Metcalfe, W. K., Kimmel, C. B., and Schabtach, E. (1985). Anatomy of the posterior lateral line system in young larvae of the zebrafish. J. Comp. Neurol. 233, 377-389. doi: 10.1002/cne.902330307

Mihara, M., Erster, S., Zaika, A., Petrenko, O., Chittenden, T., Pancoska, P., et al. (2003). p53 has a direct apoptogenic role at the mitochondria. Mol. Cell. 11, 577-590. doi: 10.1016/S1097-2765(03)00050-9

Nagtegaal, A. P., Broer, L., Zilhao, N. R., Jakobsdottir, J., Bishop, C. E., Brumat, M., et al. (2019). Genome-wide association meta-analysis identifies five novel loci for age-related hearing impairment. Sci. Rep. 9:15192. doi: 10.1038/s41598-019-51630-x

Naik, H. R., Naik, H. S., Naik, T. R., Naika, H. R., Gouthamchandra, K., Mahmood, R., et al. (2009). Synthesis of novel benzo[h]quinolines: wound healing, antibacterial, DNA binding and in vitro antioxidant activity. Eur. J. Med. Chem. 44, 981-989. doi: 10.1016/j.ejmech.2008.07.006

Nicolson, T. (2017). The genetics of hair-cell function in zebrafish. J. Neurogenet 31, 102-112. doi: 10.1080/01677063.2017.1342246

Nicolson, T., Rusch, A., Friedrich, R. W., Granato, M., Ruppersberg, J. P., and Nusslein-Volhard, C. (1998). Genetic analysis of vertebrate sensory hair cell mechanosensation: the zebrafish circler mutants. Neuron 20, 271-283. doi: 10.1016/S0896-6273(00)80455-9

Noack, V., Pak, K., Jalota, R., Kurabi, A., and Ryan, A. F. (2017). An antioxidant screen identifies candidates for protection of cochlear hair cells from gentamicin toxicity. Front. Cell Neurosci. 11:242. doi: 10.3389/fncel.2017. 00242

Ohinata, Y., Miller, J. M., Altschuler, R. A., and Schacht, J. (2000). Intense noise induces formation of vasoactive lipid peroxidation products in the cochlea. Brain Res. 878, 163-173. doi: 10.1016/S0006-8993(00)02733-5

Ohlemiller, K. K., Wright, J. S., and Dugan, L. L. (1999). Early elevation of cochlear reactive oxygen species following noise exposure. Audiol. Neurootol. 4, 229-236. doi: 10.1159/000013846

Oishi, N., and Schacht, J. (2011). Emerging treatments for noiseinduced hearing loss. Expert. Opin. Emerg. Drugs 16, 235-245. doi: $10.1517 / 14728214.2011 .552427$

Olive, R., Wolf, S., Dubreuil, A., Bormuth, V., Debregeas, G., and Candelier, R. (2016). Rheotaxis of larval zebrafish: behavioral study of a multi-sensory process. Front. Syst. Neurosci. 10:14. doi: 10.3389/fnsys.2016.00014

Olszewski, J., Haehnel, M., Taguchi, M., and Liao, J. C. (2012). Zebrafish larvae exhibit rheotaxis and can escape a continuous suction source using their lateral line. PLoS ONE 7:e36661. doi: 10.1371/journal.pone.0036661

Ou, H. C., Keating, S., Wu, P., Simon, J. A., Raible, D. W., and Rubel, E. W. (2012). Quinoline ring derivatives protect against aminoglycoside-induced hair cell death in the zebrafish lateral line. J. Assoc. Res. Otolaryngol. 13, 759-770. doi: 10.1007/s10162-012-0353-0 
Ou, H. C., Raible, D. W., and Rubel, E. W. (2007). Cisplatin-induced hair cell loss in zebrafish (Danio rerio) lateral line. Hear. Res. 233, 46-53. doi: 10.1016/j.heares.2007.07.003

Owens, K. N., Coffin, A. B., Hong, L. S., Bennett, K. O., Rubel, E. W., and Raible, D. W. (2009). Response of mechanosensory hair cells of the zebrafish lateral line to aminoglycosides reveals distinct cell death pathways. Hear. Res. 253, 32-41. doi: 10.1016/j.heares.2009.03.001

Owens, K. N., Cunningham, D. E., MacDonald, G., Rubel, E. W., Raible, D. W., and Pujol, R. (2007). Ultrastructural analysis of aminoglycoside-induced hair cell death in the zebrafish lateral line reveals an early mitochondrial response. J. Comp. Neurol. 502, 522-543. doi: 10.1002/cne.21345

Owens, K. N., Santos, F., Roberts, B., Linbo, T., Coffin, A. B., Knisely, A. J., et al. (2008). Identification of genetic and chemical modulators of zebrafish mechanosensory hair cell death. PLoS Genet. 4:e1000020. doi: 10.1371/journal.pgen.1000020

Park, C., Ji, H. M., Kim, S. J., Kil, S. H., Lee, J. N., Kwak, S., et al. (2017). Fenofibrate exerts protective effects against gentamicin-induced toxicity in cochlear hair cells by activating antioxidant enzymes. Int. J. Mol. Med. 39, 960-968. doi: 10.3892/ijmm.2017.2916

Patergnani, S., Suski, J. M., Agnoletto, C., Bononi, A., Bonora, M., De Marchi, E., et al. (2011). Calcium signaling around mitochondria associated membranes (MAMs). Cell Commun. Signal. 9:19. doi: 10.1186/1478-811X-9-19

Pickett, S. B., Thomas, E. D., Sebe, J. Y., Linbo, T., Esterberg, R., Hailey, D. W., et al. (2018). Cumulative mitochondrial activity correlates with ototoxin susceptibility in zebrafish mechanosensory hair cells. Elife 7:e38062. doi: 10.7554/eLife.38062.026

Priuska, E. M., and Schacht, J. (1995). Formation of free radicals by gentamicin and iron and evidence for an iron/gentamicin complex. Biochem. Pharmacol. 50, 1749-1752. doi: 10.1016/0006-2952(95)02160-4

Puschner, B., and Schacht, J. (1997). Energy metabolism in cochlear outer hair cells in vitro. Hear. Res. 114, 102-106. doi: 10.1016/S0378-5955(97)00163-9

Rah, Y. C., Choi, J., Yoo, M. H., Yum, G., Park, S., Oh, K. H., et al. (2015). Ecabet sodium alleviates neomycin-induced hair cell damage. Free Radic. Biol. Med. 89, 1176-1183. doi: 10.1016/j.freeradbiomed.2015.11.007

Raible, D. W., and Kruse, G. J. (2000). Organization of the lateral line system in embryonic zebrafish. J. Comp. Neurol. 421, 189-198. doi: 10.1002/(SICI)10969861(20000529)421:2<189::AID-CNE5>3.0.CO;2-K

Rizzuto, R., Marchi, S., Bonora, M., Aguiari, P., Bononi, A., De Stefani, D., et al. (2009). $\mathrm{Ca}(2+)$ transfer from the ER to mitochondria: when, how and why. Biochim. Biophys. Acta. 1787, 1342-1351. doi: 10.1016/j.bbabio.2009.03.015

Rizzuto, R., and Pozzan, T. (2006). Microdomains of intracellular Ca2+: molecular determinants and functional consequences. Physiol. Rev. 86, 369-408. doi: 10.1152/physrev.00004.2005

Rybak, L. P. (2007). Mechanisms of cisplatin ototoxicity and progress in otoprotection. Curr. Opin. Otolaryngol. Head Neck Surg. 15, 364-369. doi: 10.1097/MOO.0b013e3282eee452

Schmitz, F., Konigstorfer, A., and Sudhof, T. C. (2000). RIBEYE, a component of synaptic ribbons: a protein's journey through evolution provides insight into synaptic ribbon function. Neuron 28, 857-872. doi: 10.1016/S0896-6273(00)00159-8

Schuknecht, H. F., and Gacek, M. R. (1993). Cochlear pathology in presbycusis. Ann. Otol. Rhinol. Laryngol. 102 (1 Pt 2), 1-16. doi: $10.1177 / 00034894931020$ S101

Schwarz, D. S., and Blower, M. D. (2016). The endoplasmic reticulum: structure, function and response to cellular signaling. Cell. Mol. Life Sci. 73, 79-94. doi: 10.1007/s00018-015-2052-6

Sheets, L., Kindt, K. S., and Nicolson, T. (2012). Presynaptic CaV1.3 channels regulate synaptic ribbon size and are required for synaptic maintenance in sensory hair cells. J. Neurosci. 32, 17273-17286. doi: 10.1523/JNEUROSCI.3005-12.2012

Sheets, L., Trapani, J. G., Mo, W., Obholzer, N., and Nicolson, T. (2011). Ribeye is required for presynaptic $\mathrm{Ca}(\mathrm{V}) 1.3 \mathrm{a}$ channel localization and afferent innervation of sensory hair cells. Development 138, 1309-1319. doi: $10.1242 /$ dev. 059451

Song, J. J., Chang, J., Choi, J., Im, G. J., Chae, S. W., Lee, S. H., et al. (2014). Protective role of NecroX-5 against neomycin-induced hair cell damage in zebrafish. Arch. Toxicol. 88, 435-441. doi: 10.1007/s00204-013-1124-3
Stawicki, T. M., Hernandez, L., Esterberg, R., Linbo, T., Owens, K. N., Shah, A. N., et al. (2016). Cilia-associated genes play differing roles in aminoglycoside-induced hair cell death in zebrafish. G3. 6, 2225-2235. doi: $10.1534 / \mathrm{g} 3.116 .030080$

Stewart, W. J., Cardenas, G. S., and McHenry, M. J. (2013). Zebrafish larvae evade predators by sensing water flow. J. Exp. Biol. 216 (Pt 3), 388-398. doi: $10.1242 /$ jeb. 072751

Suli, A., Watson, G. M., Rubel, E. W., and Raible, D. W. (2012). Rheotaxis in larval zebrafish is mediated by lateral line mechanosensory hair cells. PLoS ONE 7:e29727. doi: 10.1371/journal.pone.0029727

Szabadkai, G., Bianchi, K., Varnai, P., De Stefani, D., Wieckowski, M. R., Cavagna, D., et al. (2006). Chaperone-mediated coupling of endoplasmic reticulum and mitochondrial Ca2+ channels. J. Cell Biol. 175, 901-911. doi: $10.1083 /$ jcb. 200608073

Tait, S. W., Oberst, A., Quarato, G., Milasta, S., Haller, M., Wang, R., et al. (2013). Widespread mitochondrial depletion via mitophagy does not compromise necroptosis. Cell Rep. 5, 878-885. doi: 10.1016/j.celrep.2013. 10.034

Teitz, T., Fang, J., Goktug, A. N., Bonga, J. D., Diao, S., Hazlitt, R. A., et al. (2018). CDK2 inhibitors as candidate therapeutics for cisplatin- and noiseinduced hearing loss. J. Exp. Med. 215, 1187-1203. doi: 10.1084/jem.201 72246

Thomas, C., Mackey, M. M., Diaz, A. A., and Cox, D. P. (2009). Hydroxyl radical is produced via the Fenton reaction in submitochondrial particles under oxidative stress: implications for diseases associated with iron accumulation. Redox Rep. 14, 102-108. doi: 10.1179/135100009X392566

Ton, C., and Parng, C. (2005). The use of zebrafish for assessing ototoxic and otoprotective agents. Hear. Res. 208, 79-88. doi: 10.1016/j.heares.2005.05.005

Toyama, T., Nakamura, H., Harano, Y., Yamauchi, N., Morita, A., Kirishima, T., et al. (2004). PPARalpha ligands activate antioxidant enzymes and suppress hepatic fibrosis in rats. Biochem. Biophys. Res. Commun. 324, 697-704. doi: 10.1016/j.bbrc.2004.09.110

Tritsch, N. X., Rodriguez-Contreras, A., Crins, T. T., Wang, H. C., Borst, J. G., and Bergles, D. E. (2010). Calcium action potentials in hair cells pattern auditory neuron activity before hearing onset. Nat. Neurosci. 13, 1050-1052. doi: $10.1038 / \mathrm{nn} .2604$

Tritsch, N. X., Yi, E., Gale, J. E., Glowatzki, E., and Bergles, D. E. (2007). The origin of spontaneous activity in the developing auditory system. Nature 450, 50-55. doi: $10.1038 /$ nature 06233

Uribe, P. M., Villapando, B. K., Lawton, K. J., Fang, Z., Gritsenko, D., Bhandiwad, A., et al. (2018). Larval zebrafish lateral line as a model for acoustic trauma. eNeuro 5. doi: 10.1523/ENEURO.0206-18.2018

Vance, J. E. (1990). Phospholipid synthesis in a membrane fraction associated with mitochondria. J. Biol. Chem. 265, 7248-7256. doi: 10.1016/S0021-9258(19)39106-9

Vandenabeele, P., Vanden Berghe, T., and Festjens, N. (2006). Caspase inhibitors promote alternative cell death pathways. Sci. STKE 2006:pe44. doi: 10.1126/stke.3582006pe44

Vuckovic, D., Mezzavilla, M., Cocca, M., Morgan, A., Brumat, M., Catamo, E., et al. (2018). Whole-genome sequencing reveals new insights into age-related hearing loss: cumulative effects, pleiotropy and the role of selection. Eur. J. Hum. Genet. 26, 1167-1179. doi: 10.1038/s41431-018-0126-2

Wang, M., Liu, H., Zheng, J., Chen, B., Zhou, M., Fan, W., et al. (2016). A deafness- and diabetes-associated tRNA mutation causes deficient pseudouridinylation at position 55 in tRNAGlu and mitochondrial dysfunction. J. Biol. Chem. 291, 21029-21041. doi: 10.1074/jbc.M116.7 39482

Wells, H. R. R., Freidin, M. B., Zainul Abidin, F. N., Payton, A., Dawes, P., Munro, K. J., et al. (2019). GWAS identifies 44 independent associated genomic loci for self-reported adult hearing difficulty in UK Biobank. Am. J. Hum. Genet. 105, 788-802. doi: 10.1016/j.ajhg.2019.09.008

Wiedenhoft, H., Hayashi, L., and Coffin, A. B. (2017). PI3K and inhibitor of apoptosis proteins modulate gentamicin- induced hair cell death in the zebrafish lateral line. Front. Cell. Neurosci. 11:326. doi: $10.3389 /$ fncel.2017.00326

Wolman, M. A., Jain, R. A., Marsden, K. C., Bell, H., Skinner, J., Hayer, K. E., et al. (2015). A genome-wide screen identifies PAPP-AA-mediated IGFR 
signaling as a novel regulator of habituation learning. Neuron 85, 1200-1211. doi: 10.1016/j.neuron.2015.02.025

Wong, H. C., Zhang, Q., Beirl, A. J., Petralia, R. S., Wang, Y. X., and Kindt, K. (2019). Synaptic mitochondria regulate hair-cell synapse size and function. Elife 8:e48914. doi: 10.7554/eLife.48914.sa2

Xie, J., Talaska, A. E., and Schacht, J. (2011). New developments in aminoglycoside therapy and ototoxicity. Hear. Res. 281, 28-37. doi: 10.1016/j.heares.2011.05.008

Yamane, H., Nakai, Y., Takayama, M., Iguchi, H., Nakagawa, T., and Kojima, A. (1995). Appearance of free radicals in the guinea pig inner ear after noise-induced acoustic trauma. Eur. Arch. Otorhinolaryngol. 252, 504-508. doi: 10.1007/BF02114761

Zenisek, D., and Matthews, G. (2000). The role of mitochondria in presynaptic calcium handling at a ribbon synapse. Neuron 25, 229-237. doi: 10.1016/S0896-6273(00)80885-5

Zhang, Q., Zhang, L., Chen, D., He, X., Yao, S., Zhang, Z., et al. (2018). Deletion of Mtul (Trmu) in zebrafish revealed the essential role of tRNA modification in mitochondrial biogenesis and hearing function. Nucleic Acids Res. 46, 10930-10945. doi: 10.1093/nar/gky758
Zhao, Y., Zhao, F., Zong, L., Zhang, P., Guan, L., Zhang, J., et al. (2013). Exome sequencing and linkage analysis identified tenascin-C (TNC) as a novel causative gene in nonsyndromic hearing loss. PLoS ONE 8:e69549. doi: 10.1371/journal.pone.0069549

Zhou, S., Sun, Y., Kuang, X., Hou, S., Yang, Y., Wang, Z., et al. (2019). Mitochondria-targeting nanomedicine: an effective and potent strategy against aminoglycosides-induced ototoxicity. Eur. J. Pharm. Sci. 126, 59-68. doi: 10.1016/j.ejps.2018.04.027

Conflict of Interest: The authors declare that the research was conducted in the absence of any commercial or financial relationships that could be construed as a potential conflict of interest.

Copyright $\odot 2021$ Holmgren and Sheets. This is an open-access article distributed under the terms of the Creative Commons Attribution License (CC BY). The use, distribution or reproduction in other forums is permitted, provided the original author(s) and the copyright owner(s) are credited and that the original publication in this journal is cited, in accordance with accepted academic practice. No use, distribution or reproduction is permitted which does not comply with these terms. 